\title{
Effects of Regular Physical Exercises in the Water on the Metabolic Profile of Women with Abdominal Obesity
}

\author{
by \\ Zbigniew Kasprzak1, Łucja Pilaczyńska-Szcześniak ${ }^{1}$
}

Recreational physical exercise in the water is predominantly based on aerobic metabolism. Since it involves both carbohydrate and lipid sources of energy, aqua aerobics has a beneficial effect on metabolism of these substrates. The aim of the study was to assess the impact of a 3 month aqua aerobics training program on the metabolic profile of women with abdominal obesity. The study sample comprised 32 women aged 41-72 years. Somatic characteristics and variables characterizing carbohydrate and lipid metabolism were measured before the commencement and after the completion of the training program. During the 2 nd measurement all mean anthropometric variables were found to be significantly lower $(p \leq 0.01)$. In the blood lipid profile, the concentrations of total cholesterol, LDL-cholesterol and HOMAIR were significantly lower $(p<0.01$ ). Furthermore, the levels of fasting triglycerides, glucose and insulin were reduced significantly $(p \leq 0.05)$ after the training program.

The aqua aerobics program contributed to positive changes in lipid metabolism, anthropometric variables, as well as the fasting insulin, glucose levels and insulin resistance index in women with abdominal obesity.

Key words: water aerobics, blood lipid profile, OGTT.

\section{Introduction}

Abdominal obesity is commonly associated with hyperinsulinemia, insulin resistance and changes in the blood lipid profile. We recognize it, when waist circumference in women is at least 80 $\mathrm{cm}$ and the waist-hip ratio (WHR) is greater than 0,8 . Researchers have indicated that a greater body mass is not only accompanied by insulin hypersecretion, but also lower hepatic clearance and by peripheral insulin resistance (Fujioka et al., 1987; Goodpaster et al., 2005). The age and lifestyle of the present-day population characterized by limited physical activity and a positive energy balance additionally facilitate metabolic disturbances (Chakravarthy et al., 2002;

Karolkiewicz et al., 2009). At the same time, regular moderate physical activity, with a predominance of aerobic metabolism, is considered to be a major factor preventing obesity as well as resultant disease entities (Dylewicz et al., 2000). This is confirmed by numerous studies which found physical activity to increase insulin sensitivity, normalize the blood lipid profile and blood pressure in individuals with metabolic disorders (Gaziano et al., 1997; Dela et al., 1994).

One of the forms of regular physical activity often taken up by women includes aqua aerobics. This type of exercise is predominantly based on aerobic metabolic processes involving carbohydrate as well as lipid substrates (Romijn et al., 1993), and thus, improves carbohydrate and lipid metabolism.

The aim of the study was to evaluate the effects of a three-month recreational aqua aerobics

1 - Department of Hygiene, Chair of Physiology, Biochemistry and Hygiene, University School of Physical Education in Poznań, Poland. 
program on the metabolic profile of women with abdominal obesity.

\section{Material and Methods}

The study sample consisted of 32 women with

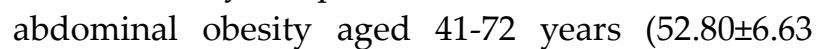
years), who declared good health. The women volunteered to participate in aqua aerobics classes twice a week, for three months (having obtained a respective permission from their primary care physician). The subjects provided their written consent to participate in the tests, and the study was approved by the Bioethical Commission of the Poznan University of Medical Sciences. During the study the participants were advised not to change their dietary habits and lifestyle.

Two measurements of somatic traits (body mass, body height, waist circumference, hip circumference) and venous blood samples were taken before and after the training program, in the morning while fasting. Body mass and body height were measured using certified equipment Radwag (Radom, Poland) with an accuracy of $0.01 \mathrm{~kg}$ (body mass) and $0.5 \mathrm{~cm}$ (body height). Waist and hip circumferences were measured according to the WHO using measuring tape inextensible. Waist circumference was measured at half the distance between the bottom edge of the last rib and iliac crest. Hip circumference was measured at the widest point of buttocks, parallel to the ground. The blood plasma levels of total cholesterol (TC), HDL-cholesterol and triglycerides (TG) were marked with commercially available tests (Cormay, Poland). Serum insulin concentration was measured with the radioimmunological test (BioSource Europe S.A., Belgium), and the glucose level was determined with an enzymatic method (Cormay, Poland). Furthermore, all subjects underwent a standard two-hour Oral Glucose Tolerance Test (OGTT). A standard load of $75 \mathrm{~g}$ of glucose (Prolab, Poland) dissolved in $250 \mathrm{ml}$ of distilled water was administered over 5 min. Venous blood was taken directly before (fasting state) and $120 \mathrm{~min}$ after glucose administration.

The LDL-cholesterol level was estimated with the Friedewald equation (Friedewald et al., 1972), and the Homeostatic Model Assessment of Insulin Resistance Index (HOMAIR) index was calculated using Matthews' equation (Matthews et al., 1985).

\section{Training program}

The training program consisted of aerobic, resistance exercises in the water to the accompaniment of music. The participants performed free exercises and exercises with props (flotation belts, rubber springs, dumbbell). The classes took place twice a week, and each class lasted $60 \mathrm{~min}$. Each class began with a 10-12-min warm-up, which consisted of exercises of progressive intensity. Then, the participants performed aerobic exercises for $40 \mathrm{~min}$, strength exercises for 5-10 min, and cool-down exercises for 2-3 min. The intensity of the aerobic exercises corresponded to $65-75 \% \mathrm{HR}_{\max }\left[\mathrm{HR}_{\max }=220-\right.$ age (years)]. The heart rate was measured with a SportTester (Polar Elektro Oy, Finland). In the last 8-10 min of each session the participants performed stretching and relaxing exercises.

\section{Statistical analysis}

The variables were presented using descriptive statistics: arithmetic means $(\bar{x})$, standard deviations (SD), minimum (min) and maximum (max) values and confidence interval of 95\% (95\% CI). For variables with a normal distribution significance of differences between the measurements were assessed using the t-test. For variables with a non-normal distribution the nonparametric Wilcoxon signed-rank test was used. The level of statistical significance was set at $p \leq 0.05$. All statistical calculations were made using the STATISITICA 10 software package.

\section{Results}

Table 1 shows the mean values $(\bar{x} \pm \mathrm{SD})$ of somatic traits of the study participants, while Table 2 presents variables of lipid and carbohydrate metabolism measured before and after the training program. After the completion of the program, a significant reduction of the mean values of all somatic characteristics, i.e. body mass, BMI, waist circumference, hip circumference and the WHR index $(p \leq 0.01)$ was registered. The highest statistically significant reduction of lipid profile components was found for total cholesterol, LDLcholesterol and HOMAIR $(\mathrm{p} \leq 0.01)$. The concentrations of triglycerides, insulin and glucose were reduced at $\mathrm{p}<0.05$ (Table 2).

Figures 1 and 2 present mean glucose and insulin levels during the OGTT test, during the measurements, whereas Figure 3 illustrates the HOMAIr mean values. Between the measurements a significant reduction of fasting insulin, glucose and HOMAIR was found $(\mathrm{p}<0.05)$, whereas after 120 
min of the test the differences were statistically nonsignificant.

\section{Discussion}

The obtained results correspond to those of other researchers indicating that systematic physical activity has a beneficial impact on morphological variables (Blair et al., 2001) and the blood lipid profile (Horowitz, 2001; Nowak et al., 2008) in obese individuals. These changes can be explained, on one hand, by the increased oxidation of free fatty acids and the improved function of the mitochondria (Horowitz, 2001), and on the other hand by increased insulin sensitivity (PilaczyńskaSzcześniak et al., 2005; Mayer-Davis et al., 1998) due to the greater activity of GLUT-4 glucose transporters sensitive to muscle contraction (Cortright and Dohm, 1997; Thorell et al., 1999). It is emphasized that the intensivity of lipid metabolism during physical exercise in the water is conditioned by its temperature. During the thermoneutral immersion (water temperature $32-34^{\circ} \mathrm{C}$ ) there is no heat loss from the human body. The main stimulus that increases the mobilization and oxidation of free fatty acids during prolonged exercise in such conditions is the activation of the sympathetic and adrenal-cortical system and increased release of catecholamines (Stokes et al., 2004). However, in lower water temperature not only the vasoconstriction of the skin occurs, also in the subcutaneous fat issue, which results in reduced blood flow to the tissues in which the fat is deposited. For this reason, mobilization and oxidation of free fatty acids is lower than that indicated by activation of the sympathetic nervous system (Wilmore and Costill, 2008).

Table 1

Comparative analysis of somatic variables of studied subjects between the $1^{\text {st }}$ and $2^{\text {nd }}$ measurements

\begin{tabular}{|c|c|c|c|c|}
\hline \multirow[t]{2}{*}{ Variables } & \multicolumn{2}{|c|}{$\begin{array}{c}\bar{x} \pm \mathrm{SD} \\
(\min ; \max )\end{array}$} & \multirow[t]{2}{*}{$95 \% \mathrm{CI}$} & \multirow[t]{2}{*}{$\mathrm{p}$} \\
\hline & $1^{\text {st }}$ measurement & $2^{\text {nd }}$ measurement & & \\
\hline $\begin{array}{l}\text { Body mass } \\
{[\mathrm{kg}]}\end{array}$ & $\begin{array}{l}87.08 \pm 14.61 \\
(65.8 ; 118.5)\end{array}$ & $\begin{array}{l}85.73 \pm 14.95 \\
(63.5 ; 118.0)\end{array}$ & $0.71-1.99$ & 0.0001 \\
\hline $\begin{array}{l}\text { BMI } \\
{\left[\mathrm{kg} / \mathrm{m}^{2}\right]}\end{array}$ & $\begin{array}{r}32.60 \pm 4.81 \\
(25.7 ; 42.0)\end{array}$ & $\begin{array}{l}32.11 \pm 4.98 \\
(24.2 ; 41.8)\end{array}$ & $0.27-0.74$ & 0.0001 \\
\hline $\begin{array}{l}\text { Waist } \\
\text { circumference }[\mathrm{cm}]\end{array}$ & $\begin{array}{c}101.63 \pm 11.25 \\
(80,0 ; 124,1)\end{array}$ & $\begin{array}{l}95.34 \pm 11.27 \\
(77,0 ; 119,0)\end{array}$ & $4.90-7.67$ & $<0.0001$ \\
\hline $\begin{array}{l}\text { Hip circumference } \\
{[\mathrm{cm}]}\end{array}$ & $\begin{array}{c}115.41 \pm 10.55 \\
(96,0 ; 144,2)\end{array}$ & $\begin{array}{c}111.00 \pm 10.10 \\
(92,3 ; 130,0)\end{array}$ & $2.20-6.62$ & $<0.0001$ \\
\hline WHR & $\begin{array}{c}0.89 \pm 0.05 \\
(0.8 ; 1.0)\end{array}$ & $\begin{array}{c}0.86 \pm 0.05 \\
(0.7 ; 1.0)\end{array}$ & $0.02-0.75$ & 0.0002 \\
\hline
\end{tabular}

Significant difference $(p<0.05)$ 
Table 2

Mean values $(x \pm S D)$ of variables of carbohydrate and lipid metabolism in studied subjects

\begin{tabular}{|c|c|c|c|c|}
\hline \multirow[t]{2}{*}{ Variables } & \multicolumn{2}{|c|}{$\begin{array}{c}\bar{x} \pm \mathrm{SD} \\
(\min ; \max )\end{array}$} & \multirow[t]{2}{*}{$95 \% \mathrm{CI}$} & \multirow[t]{2}{*}{$\mathrm{p}$} \\
\hline & $1^{\text {st }}$ measurement & $2^{\text {nd }}$ measurement & & \\
\hline $\begin{array}{l}\text { TG } \\
{[\mathrm{mg} / \mathrm{dl}]}\end{array}$ & $\begin{array}{l}99.79 \pm 44.78 \\
(38.8 ; 215.5)\end{array}$ & $\begin{array}{l}91.66 \pm 39.26 \\
(41,0 ; 197.3)\end{array}$ & $2.36-13.91$ & 0.0261 \\
\hline $\begin{array}{l}\text { LDL } \\
{[\mathrm{mg} / \mathrm{dl}]}\end{array}$ & $\begin{array}{c}111.33 \pm 33.33 \\
(53.3 ; 207.1)\end{array}$ & $\begin{array}{c}102.03 \pm 29.53 \\
(56.3 ; 175.9)\end{array}$ & $3.65-14.95$ & 0.0021 \\
\hline $\begin{array}{l}\text { HDL } \\
{[\mathrm{mg} / \mathrm{dl}]}\end{array}$ & $\begin{array}{c}59.54 \pm 15.912 \\
(33.2 ; 91.6)\end{array}$ & $\begin{array}{c}58.37 \pm 12.69 \\
(37.8 ; 88.7)\end{array}$ & $0.01-4.18$ & 0.3126 \\
\hline $\begin{array}{l}\text { Total } \\
\text { cholesterol } \\
{[\mathrm{mg} / \mathrm{dl}]}\end{array}$ & $\begin{array}{l}190.81 \pm 33.41 \\
(133.8 ; 285.6)\end{array}$ & $\begin{array}{l}179.36 \pm 28.85 \\
(130,0 ; 253.7)\end{array}$ & $5.80-17.10$ & 0.0003 \\
\hline $\begin{array}{l}\text { Glucose } \\
{[\mathrm{mmol} / \mathrm{l}]}\end{array}$ & $\begin{array}{c}4.94 \pm 0.80 \\
(3.6 ; 7.0)\end{array}$ & $\begin{array}{c}4.55 \pm 0.63 \\
(3.4 ; 6.4)\end{array}$ & $0.02-0.75$ & 0.0377 \\
\hline $\begin{array}{l}\text { Insulin } \\
{[\mu \mathrm{IU} / \mathrm{ml}]}\end{array}$ & $\begin{array}{c}11.4 \pm 4.842 \\
(5.1 ; 22.3)\end{array}$ & $\begin{array}{l}9.81 \pm 4.47 \\
(5,0 ; 25.7)\end{array}$ & $0.39-2.78$ & 0.0194 \\
\hline HOMAIR & $\begin{array}{c}2.54 \pm 1.24 \\
(1.0 ; 5.5)\end{array}$ & $\begin{array}{c}1.99 \pm 0.97 \\
(0.8 ; 5.5)\end{array}$ & $0.21-0.89$ & 0.0067 \\
\hline
\end{tabular}

Significant difference $(p<0.05)$

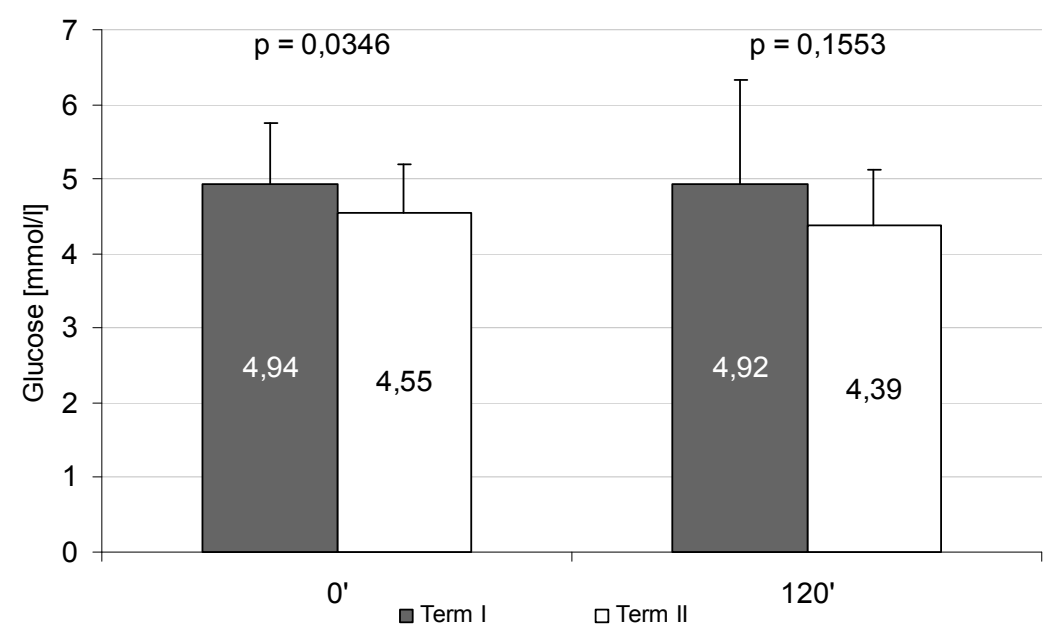

Figure 1

Significant difference $(p<0.05)$

Mean glucose concentration during an oral glucose tolerance test (OGTT) between the measurements 


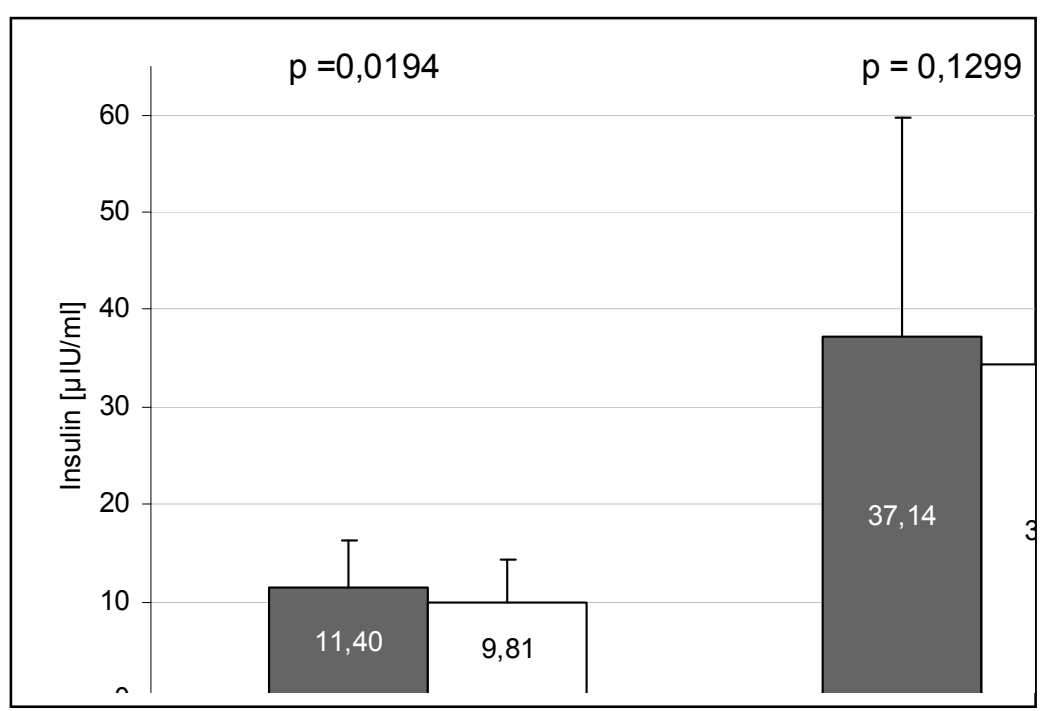

Significant difference $(p<0.05)$

Figure 2

Mean insulin concentrations during an oral glucose tolerance test (OGTT) between the measurements

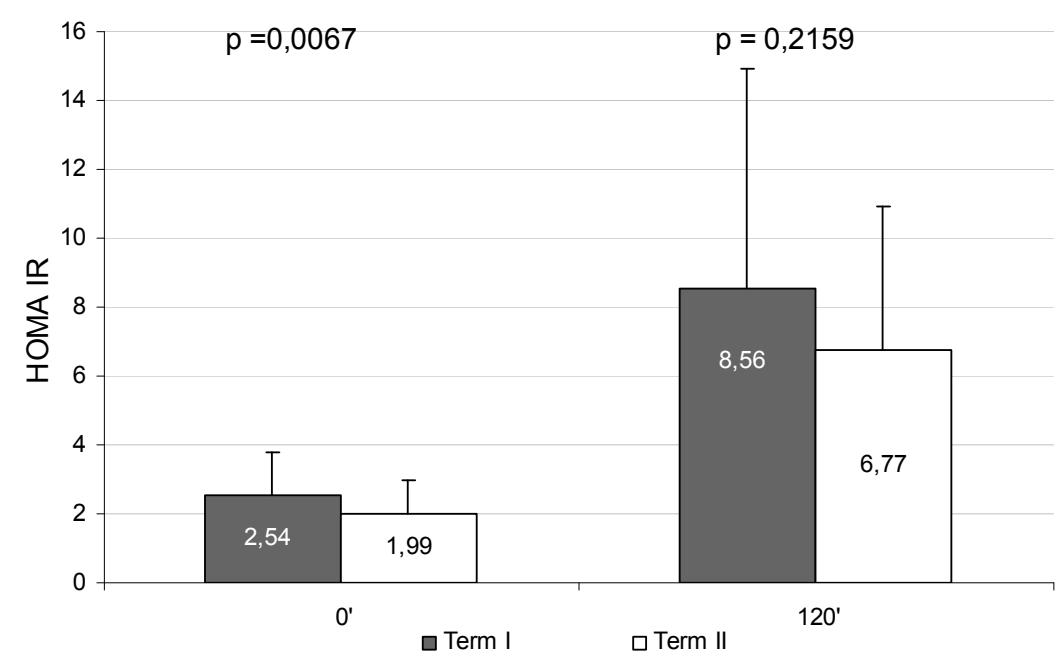

Figure 3

Significant difference $(p<0.05)$

Mean HOMAIR index during the oral glucose tolerance test (OGTT) between the measurements 
The majority of studies on the effects of physical activity on lipid metabolism in individuals with abdominal obesity points to the normalization of HDL-cholesterol and TG levels, as the latter are considered to be the main source of free fatty acids utilized during physical activity (Horowitz, 2001). Regular physical exercise contributes to an increase of insulin-dependent lipoprotein lipase (LPL) in the adipose tissue and muscles as well as to the decreased activity of hepatic lipase, all of which leads to a reduction of the triglycerides level. An increase in the LDL-cholesterol level is related to the greater demand for free fatty acids as an energy substrate during muscle work and to the replenishment of muscle and cell membrane phospholipid supplies to repair eccentric exerciseinduced myofibril damage (Nikilaidis et al., 2008). The restoration of intramuscular and membrane phospholipids by the fatty acids is thought to play the main role in the process of TG reduction in blood serum (Nikilaidis et al., 2008).

The implemented training program contributed to significant changes in the LDLcholesterol level, which could have been related to the reduction of body girths and thus changes in body composition (Table 1). After the completion of the program BMI was lowered by $1.5 \%$, and WHR by $4 \%$. The noted reduction of total cholesterol $(p<0.01)$ corresponds with the results of Thompson et al. (1979), according to whom an increased energy expenditure during physical exercise is conducive not only to a lower total cholesterol but may also induce a reduction of HDL-cholesterol level due to a decrease in the synthesis of total cholesterol as indicated by the results of the present study (Table 2).

The obtained results are contradictory to those of Viljoen and Christe (2011), who after a 24week resistance training program (three times a week) in menopausal women, not only failed to find any positive changes in blood lipid profile, but also noted higher TG and LDL concentrations. In their study, Viljoen and Christe assumed no changes in the subjects' body mass, while in the present work this assumption was not taken into account. Moreover, our training program, apart from resistance exercises, included also endurance exercises. Therefore, the observed positive changes in the blood lipid profile could be the effect of the beneficial impact of physical activity not only on body mass but, first and foremost, on body composition as confirmed by the WHR and BMI values. Our results correspond to earlier results of King et al. (1995) and Spate-Douglas and Keyser (1999).

The literature on the subject shows that regular physical exercise improves insulin sensitivity by increasing muscle contraction-related glucose transport (Santos et al., 2008; Farese, 2002; Fuerger et al., 2004), muscle blood flow (Suh et al., 2007) as well as expression and translocation of GLUT-4 glucose transporters and the encoding mRNA (McGee and Hargreaves, 2006). Physical exercise also increases the activity of phosphatidylinositide 3-kinase (PI3K) in the insulin receptor and the activity of insulin receptor substrate 1 (Arias et al., 2001; McGee and Hargreaves, 2006), thus increasing the receptor's affinity to the agonist (Szcześniak et al., 1998). As far as carbohydrate metabolism is concerned a significant decrease of fasting insulin and glucose levels $(p<0.05)$ and HOMAIr $(p<0.01)$ was noted after the completion of the training program. In the $120^{\text {th }}$ min of the OGTT test, the lower mean values of insulin and glucose concentrations were statistically non-significant. Pratley et al. (2000), after their training program lasting a few months (45-60 min, 3-4 times a week), noted a reduction in waist circumference, abdominal fat mass and insulin response in the OGTT, despite no changes in fasting glucose and insulin. The analysis of regression in Pratley et al. (2000) showed that changes in the waist circumference and percent of abdominal fat were independent factors of reduction of the late-phase insulin response during the OGTT. According to the American Heart Association and the American College of Sport Medicine, physical exercises of moderate intensity five times a week are recommended in preventive medicine (Haskell et al., 2007; Garber et al., 2011). Following these recommendations a concurrent decrease in the insulin and glucose levels should be obtained in the $120^{\text {th }}$ min of the test.

In the present study a 2.5 higher HOMAIR in the first measurement (Table 2) was conditioned by both abdominal fat mass (Kahn and Flier, 2000) and age (Mazumdar et al., 2004). According to Ryan (2000), the most frequent cause for increasing insulin resistance with age is not age itself but the reduction of lean body mass, increasing visceral fat mass, neuro-hormonal changes and a lower physical activity level. The lower mean HOMAIR 
found in the present study, after three months of systematic physical exercise in the water, allows to recognize the significant effects of physical activity on the development of peripheral insulin resistance.

\section{Conclusion}

The obtained study results show that a 3 month aqua aerobics training program greatly contributed to positive changes in lipid metabolism, anthropometric variables and fasting levels of insulin, glucose and insulin resistance index. The participation in the training program did not, however, bring any changes in the resting HDL level and insulin, glucose and HOMAIr levels in the $120^{\text {th }} \mathrm{min}$ of the OGTT. Possibly greater weekly training loads or a longer training program might bring such changes.

\section{References}

Arias EB, Gosselin LE, Cartee GD. Exercise training eliminates age-related differences in skeletal muscle insulin receptor and IRS-1 abundance in rats. J Gerontology, 2001; 56, 10: B449-B455

Blair S, Cheng Y, Holder J. Is physical activity or physical fitness more important in defining health benefits? Med Sci Sports Exerc, 2001; 33: 379-399

Chakravarthy MV, Joyner MJ, Booth FW. An obligation for primary care physicians to prescribe activity to sedentary patients to reduce the risk of chronic health conditions. Mayo Clin Proc, 2002; 77: 165-173

Cortright RN, Dohm GL. Mechanism by which insulin and muscle concentration stimulate glucose transport. Can J Appl Pysiol, 1997; 22: 519-530

Dela F, Mikines KJ, Sonne B, Galbo H. Effect of training on interaction between insulin and exercise in human muscle. J Appl Physiol, 1994; 76: 2386-2393

Dylewicz P, Bieńkowska S, Szcześniak Ł, Rychlewski T, Przywarska I, Wilk M, Jastrzębski A. Beneficial effect of short-term endurance training on glucose metabolism during rehabilitation after coronary bypass surgery. CHEST, 2000; 117(1): 47- 51

Farese RV. Function and dysfunction of aPKC isoforms for glucose transport in insulin-sensitive and insulinresistance states. Am J Physiol Endocrinol Metab, 2002; 283: E1-E11

Friedewald WT, Levy RI, Fredrickson DS. Estimation of the concentration of low-density lipoprotein cholesterol in plasma, without use of the preparative ultracentrifuge. Clin Chem, 1972; 18: 499-502

Fuerger PT, Bracy DP, Malabanan CM, Pencek RR, Wasermann DH. Distributed control of glucose uptake by working muscles of conscious mice: role of transport and phosphorylation. Am J Physiol Endocrinol Metab, 2004; 286: E77-E84

Fujioka S, Matsuzawa Y, Tokunga K, Tarui S. Contribution of intra-abdominal fat accumulation to the impairment of glucose and lipid metabolism in human obesity. Metabolism, 1987; 36: 54-59

Garber CE, Blissmer B, Deschenes MR, Franklin BA, Lamonte MJ, Lee IM, Nieman DC, Swain DP. American College of Sports Medicine position stand. Quantity and quality of exercise for developing and maintaining cardiorespiratory, musculoskeletal, and neuromotor fitness in apparently healthy adults: guidance for prescribing exercise. Med Sci Sports Exerc, 2011; 43(7): 1334-1359

Gaziano JM, Hennekens CH, O'Donnell CA, Breslow JL, Buring JE. Fasting triglicerides, high density lipoprotein and risk of myocardial infarction. Circulation, 1997; 96: 2520-2525

Goodpaster BH, Krishnaswami S, Harris TB, Katsiaras A, Kritchevsky SB, Simonick EM. Obesity, regional body fat distribution, and the metabolic syndrome in older men and women. Arch Intern Med, 2005; 165(7): 777-783

Haskell WL, Lee IM, Pate RR, Powell KE, Blair SN, Franklin BA, Macera CA, Heath GW, Thompson PD, Bauman A. Physical activity and public health: updated recommendation for adults from the American College of Sports Medicine and the American Heart Association. Med Sci Sports Exerc, 2007; 39(8): 1423-1434

(C) Editorial Committee of Journal of Human Kinetics 
Horowitz J. Regulation of lipid mobilization and oxidation during exercise in obesity. Exerc Sport Sci Rev, 2001; 29: 42-46

Kahn BB, Flier JS. Obesity and insulin resistance. J Clin Invest, 2000; 106:473-481

Karolkiewicz J, Pilaczyńska-Szcześniak Ł, Elegańczyk-Kot H, Nowak A, Kasprzak Z, Lewandowska M. Association between body mass index and insulin resistance parameters and oxidative stress markers in elderly women. Gerontol Pol, 2009; 17(2): 1-15

King AC, Haskell WL, Young DR, Oka RK, Stefanick ML. Long-term effects of varying intensities and formats of physical activity on participation rates, fitness and lipoproteins in men and women aged 50 to 65 years. Circulation, 1995; 91: 2596-2604

Matthews DR, Hosker JP, Rudensky AS, Naylor BA, Treacher DF, Turner RRR. Homeostasis model assessment: insulin resistance and beta-cell function from fasting plasma glucose and insulin concentration in man. Diabetes, 1985; 28: 412-419

Mayer-Davis EJ, D'Agostino R, Karter AJ, Haffner SM, Rewers MJ, Saad M, Bergman RN. Intensity and amount of physical activity in relation to insulin sensitivity. The Insulin Resistance and Atherosclerosis Study (IRAS). JAMA, 1998; 279: 669-674

Mazumdar R, Ma X, Atzmon G, Vuguin P, Yang X, Barzilai N. Decrease in glucose-stimulated insulin secretion with aging is independent of insulin action. Diabetes, 2004; 53: 441-446

McGee SL, Hargreaves M. Exercise and skeletal muscle glucose transporter 4 expression: molecular mechanisms. Clin Exp Pharmacol Physiol, 2006; 33(4): 395-399

Nikilaidis MG, Paschalis V, Giakas G, Fatouros JG, Sakellariou GK, Theodorou AA, Koutedakis Y, Jamurtas AZ. Favorable and prolonged changes in blood lipid profile after muscle-damaging exercise. Med Sci Sports Exerc, 2008; 40: 1483-1489

Nowak A, Pilaczyńska-Szcześniak Ł, Śliwicka E, Deskur-Śmielecka E, Karolkiewicz J, Piechowiak A. Insulin resistance and glucose tolerance in obese women: the effects of a recreational training program. $J$ Sports Med Phys Fitness, 2008; 48(2): 252-258

Pilaczyńska-Szcześniak Ł, Maciaszek J, Deskur-Śmielecka E, Nowak A, Karolkiewicz J, Rychlewski T, Osiński W. The effect of Tai-Chi training on surrogate index of insulin resistance (HOMAIR) in elderly subjects. Hum Mov, 2005; 6(2): 98-103

Pratley R, Hagberg J, Dengel D, Rogus E, Muller D, Goldgerg A. Aerobic exercise training-induced reductions in abdominal fat and glucose-stimulated insulin responses in middle-aged and older men. $J$ Am Geriatr Soc, 2000; 48: 1055-1061

Romijn JA, Coyle EF, Sidosis LS, Gastaldelli A, Horowitz JF, Endert E, Wolfe C. Regulation of endogenous fat and carbohydrate metabolism in relation to exercise intensity and duration. Am J Physiol,1993; 265: E380-E391

Ryan AS. Insulin resistance with aging. Effects of diet and exercise. Sports Med, 2000; 30: 327-346

Santos JM, Ribero SB, Gaya AR, Appell HJ, Duarte JA. Skeletal muscle pathways of concentration-enhanced glucose uptake. Int J Sports Med, 2008; 29: 785-794

Spate-Douglas T, Keyser RE. Exercise intensity: its effects on the high density lipoprotein profile. Arch Phys Med Rehab, 1999; 26: 358-364

Stokcs JM, Taylor NAS, Tipton MJ, Greenleaf JE. Human physiological responses to cold exposure. Aviat SpaceEnviron Med, 2004; 75(5): 444-457

Suh SH, Paik IY, Jacobs K. Regulation of blood glucose homeostasis during prolonged exercise. Mol Cells, 2007; 23: 272-279

Szcześniak Ł, Karolkiewicz J, Deskur E, Rychlewski T, Konys L, Stankiewicz K. The influence of exerciseinduced oxidative stress on binding and degradation of 125I-insulin by the receptors on erythrocytes. $J$ Physiol Pharmacol, 1998; 49(3): 421-432 
Thompson PD, Jeffrey RW, Wing RR, Wood PD. Unexpected decrease in plasma high density lipoprotein cholesterol with weight loss. Am J Clin Nutr, 1979; 32(10): 2016-2021

Thorell A, Hirshman MF, Nygren J, Jorfeldt L, Wojtaszewski JFP, Dufrensne SD, Horton ES, Ljungqvist O, Goodyear LJ. Exercise and insulin cause GLUT-4 translocation in human skeletal muscle. Am J Physiol, 1999; 277: E733-E741

Viljoen JE, Christe CJA. Resistance training and changes to plasma lipoproteins in postmenopausal women. SAJSM, 2011; 23: 2, 40-44

Wilmore JH, Costill DL. Exercise In hot and cold environments: Thermoregulation. In: Physiology of Sports and Exercise. Champaign: Human Kinetics, 252-277; 2008

\section{Corresponding author:}

\section{Łucja Pilaczyńska-Szcześniak}

University School of Physical Education in Poznań

Department of Hygiene

61-871 Poznań, Królowej Jadwigi 27/39

Phone: 618355177

E-mail: szczesniak@awf.poznan.pl 